\title{
Mobile Learning Based on Procedural and Conceptual Knowledge on Fractional for Elementary School
}

\section{Anis Andriah', Mohammad Faizal Amir ${ }^{2 *}$}

1,2 Elementary School Teacher Education Department, Universitas Muhammadiyah Sidoarjo, Indonesia

\section{ART ICLE INFO}

\section{Article history:}

Received August 08, 2021

Revised August 11, 2021

Accepted October 20, 2021

Available online November 25, 2021

Kata Kunci:

Mobile Learning, Hasil Belajar,

Pecahan

Keywords:

Mobile learning, Learning

Outcome, Fraction

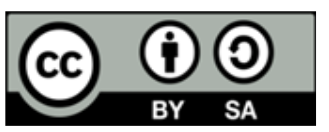

This is an open access article under the CC BY-SA license.

Copyright $\Subset 2021$ by Author. Published by Universitas Pendidikan Ganesha.

\begin{abstract}
A B S T RAK
Pandemi Covid-19 mengharuskan pembelajaran dilakukan secara jarakjauh yang menuntut guru mampu membuat pembelajaran lebih menarik dan tetap dapat mewujudkan tujuan pembelajaran. Penelitian ini bertujuan untuk menghasilkan produk yang valid, praktis dan efektif berupa mobile learning berbasis pengetahuan prosedural dan konseptual bagi siswa sekolah dasar. Penelitian ini menggunakan Research and Development dengan model ADDIE. Subjek penelitian ini adalah 11 siswa kelas $V$ sekolah dasar. Ahli materi dan media masingmasing terdiri dari satu dosen pendidikan matematika dan satu dosen pendidikan teknologi informasi. Uji validitas dilakukan secara expert judgment. Uji kepraktisan dan efektivitas masing-masing dinilai oleh 11 siswa kelas $V$ sekolah dasar untuk mengetahui respon dan hasil belajar matematika pecahan setelah menggunakan mobile learning yang dikembangkan. Data penelitian ini terdiri dari data kuantitatif dan kualitatif. Teknik pengumpulan data menggunakan kuisioner dan tes hasil belajar. Validitas mobile learning diperoleh rata-rata sebesar 3.59 atau berada pada interval $2.50 \leq R v \leq 4.00$ dengan kriteria valid. Efektivitas mobile learning diperleh dari data pre-test dan post-test. Kepraktisan mobile learning diperoleh rata-rata 3.82 atau berada pada interval $2.50 \leq R k \leq 4.00$ dengan kriteria praktis. Efektifitas mobile learning diperoleh nilai signifikansi 0,0010 atau < 0.0050 yang berarti terdapat perbedaan hasil belajar siswa sebelum penggunaan mobile learning dan sesudah penggunaan mobile learning. Dengan demikian, pengembangan mobile learning berbasis prosedural dan konseptual pada materi pecahan kelas $V$ sekolah dasar dikatakan valid, praktis dan efektif.
\end{abstract}

\begin{abstract}
A B S T R A C T
As the impact of the Covid-19 pandemic, distance learning requires teachers to make learning more interesting yet achieve learning outcomes. This study aims to produce a valid, practical, and effective product in mobile learning based on procedural and conceptual knowledge for elementary school students. This study uses Research and Development with the ADDIE model. The subjects of this study were 11 elementary school fifth-grade students. The material and media expert is a lecturer in mathematics education and information technology education, respectively. The validity test was carried out using the expert judgment method. Eleven fifth-grade elementary school students assessed the practicality and effectiveness tests to determine the responses and results in fractional mathematics after using the developed mobile learning. This study uses both quantitative and qualitative data, which were collected using questionnaires and learning outcomes tests. The validity of mobile learning produces an average of 3.59 or is in the interval $2.50 \leq R v \leq 4.00$ with valid criteria. The effectiveness of mobile learning is obtained from the pretest and posttest data. The practicality of mobile learning obtained an average of 3.82 or is in the interval $2.50 \leq \mathrm{Rk} \leq 4.00$ with practical criteria. The effectiveness of mobile learning shows a significance value of 0.0010 or $<0.0050$, which means that there are differences in student learning outcomes before and after using mobile learning. Thus, the development of procedural and conceptual-based mobile learning on fractional material in fifth-grade elementary school can be categorized as valid, practical, and effective.
\end{abstract}




\section{INTRODUCTION}

Governments worldwide are restricting social activities, businesses, and entertainment centers to stop the spread of the Covid-19 virus during the pandemic. The spread of this virus initially attacked the world economy, but now the education sector is also affected. This condition requires various countries to make regulations and fast actions to prevent the spread through social restrictions (Khachfe et al., 2020). Social restrictions that affect the academic environment include the postponement or cancellation of academic activities, seminars, workshops, conferences, and other activities (Mishra, Gupta, \& Shree, 2020; Oyedotun, 2020; Patricia, 2020; Sahu, 2020). Many countries, including Indonesia, have stopped all educational activities with a face-to-face platform so that educational institutions and governments must present alternative educational processes for students. Currently, many Indonesian schools are implementing distance learning or online (Abidin, Hudaya, \& Anjani, 2020; Astalini, Darmaji, Kurniawan, Khairul, \& Kurniawan, 2019; Harahap, Harahap, \& Harahap, 2020). Online learning frees students and educators from the obligation to meet in a room, engages students in a learning process, and, most importantly, makes learning more flexible (Bano, Zowghi, Kearney, Schuck, \& Aubusson, 2018; Peiyan, 2021; Weisberger, Grinshtain, \& Blau, 2021). Online learning can help students understand abstract material, develop collaborative learning, reasoning, and problem-solving activities (Damian, Naibaho, Agung, \& Wulandari, 2021). Online learning allows students to share opinions and learn independently without any time limit and more flexible space (Hwang, Wang, \& Lai, 2020; Lage-Cala, Folgueras-Díaza, Alonso-Hidalgoa, García-Menéndezb, \& Fernández-Garcíab, 2020). Therefore, online learning can prevent the spread of Covid-19. Nevertheless, educators must create a learning atmosphere under current conditions, student characteristics, and, of course, national education goals. Online learning requires the ability of students and educators to use technology to be able to create a comfortable learning atmosphere.

One of the lessons that allow online learning to be done is mathematics (Herzamzam, 2021). In Indonesia, elementary school mathematics learning is carried out thematically for lower classes (first, second, third-grade) integrated into learning themes. Meanwhile, mathematics learning is carried out separately from other themes or subjects for high grades (fourth, fifth, and sixth grades). Mathematics learning in elementary schools is oriented to students' ability to master mathematical concepts (Sulastri, 2016). Learning mathematics includes two interrelated aspects, namely procedural and conceptual knowledge (Hamdani, 2016; Legesse, Luneta, \& Ejigu, 2020). Procedural knowledge is defined as procedures, formulas, and steps for mathematical solutions. In contrast, conceptual knowledge is defined as basic knowledge that connects pieces of information in the form of facts, skills, concepts, or principles (Rafiq \& Mailili, 2019; Rittle-johnson \& Schneider, 2019). In other words, procedural knowledge includes formulas or solving steps. In comparison, conceptual knowledge defines a concept, what kind of formula can be generated. Conceptual knowledge can provide a good understanding of concepts for students. However, if conceptual knowledge is not balanced with procedural knowledge, students will find it difficult to solve a problem. On the other hand, if only procedural knowledge is understood, students will easily manipulate symbols and solve a problem but do not understand what they are doing (Galvin, Dütschke, \& Weiß, 2021; Oppermann \& Lazarides, 2021; Talib, 2017; Wawan, Talib, \& Djam'an, 2019). Thus, students with good procedural and conceptual knowledge will learn mathematics better and meaningfully to impact positive mathematics learning outcomes.

The results of previous studies show the low level of procedural and conceptual knowledge of elementary school students, especially on fractions. Students' difficulties in using procedural and conceptual knowledge can be detected based on the relatively low average percentage of students, $43.86 \%$ (Suarjana, Parmiti, \& Safitri, 2018). Students' difficulty in making creative solutions to fraction problems is due to elementary school students' mathematical knowledge based on recitation and procedure (Abqari, Irawan, \& Sa'dijah, 2018). Students also have difficulty activating conceptual knowledge in understanding the meaning of fractional problems in stories and modeling them into mathematical statements (Mukrimatin, Murtono, \& Wanabuliandri, 2018). The students' abstraction and visual abilities are also low, so they have difficulty describing concepts (Suhady, Roza, \& Maimunah, 2019). Students also have limitations because they only understand the form of fractions $\frac{a}{b}$, but they cannot interpret fractions (Suwarto, 2018). Analysis of procedural and conceptual knowledge shows that students still make mistakes and have low learning outcomes in solving mathematical representation problems (Devi \& Amir, 2021). The low procedural and conceptual knowledge resulted in elementary school students' mathematics learning outcomes on fractions. Based on the results of observations in class V SDN 4 Donomulyo Malang, it was found that conceptual knowledge in the preliminary material on fractions was still low. This low conceptual knowledge is indicated by the procedure for solving student fractions which is still recitation. In addition, $70 \%$ (8 out of 11) students got a math grade below the Minimum Completeness Criteria (KKM) on the daily test $(<70)$. 
Various alternative learning media are presented to solve problems related to the lack of procedural and conceptual knowledge, but the existing learning media have not constructed both pieces of knowledge. The results of the development of multimedia tutorials to facilitate procedural cognition positively impact students' procedural cognitive ability (Sari, Degeng, \& Praherdhiono, 2021). The use of puzzle board learning media increases the mathematics conceptual knowledge of elementary school students (Afra, Rahmawati, \& Widya, 2020). The use of puzzle board learning media increases the mathematics conceptual knowledge of elementary school students (Nurhayati, Aswar, \& Arifin, 2018). Youtube videos are also used as online learning media in math subjects during the Covid-19 pandemic (Humaidi, Qohar, \& Rahardjo, 2021). Therefore, there needs to be a variety of learning media, especially technological media, that are appropriate for use in online learning during the covid-19 pandemic so that student understanding can be built constructively based on procedural and conceptual knowledge.

Mobile learning is an alternative for students in understanding mathematics learning materials online because this is a wireless medium that can be accessed at any time and has special functions and features to support students (Demir \& Akpinar, 2018). Mobile learning promotes active learning, encourages students who lack self-confidence, and increases the frequency of student interactions (Parsazadeh, Ali, \& Rezaei, 2018). Mobile learning makes students no longer learn teacher-centered, so they have the freedom to develop their abilities (Chen \& Tsai, 2021; Sletten \& Montebello, 2021). Mobile learning produces online learning solutions for students that can be used anywhere and anytime (Amir, Ariyanti, Anwar, Valentino, \& Afifah, 2020; Amir, Hasanah, \& Musthofa, 2018; Jou, Tennyson, Wang, \& Huang, 2016; Saputra, Utami, \& Kusuma, 2021). The use of mobile learning accompanies student learning activities independently because it is developed with an android system like gadget applications in general (Legesse et al., 2020; Nurhalimah, Suhartono, \& Cahyana, 2017).

Previous studies have carried out variations in the development of mobile learning, one of which is the development of augmented reality-based mobile learning to improve the development of elementary school PSTs' mathematical understanding (Amir et al., 2020). The results of developing problem-solvingbased mobile learning can improve the reasoning skills of elementary school teacher education students (Amir et al., 2018). Other research develops mobile learning-based mathematics learning media with a scientific approach to improve students' mathematical performance (Nugroho \& Purwati, 2018). Developing android-based mobile learning improves students' understanding of concepts (Widiastika, Hendracipta, \& Syachruroji, 2021). The results of the development of STEM-based mobile learning (science, technology, engineering, and mathematics) can improve the learning outcomes of elementary school students (Firdaus \& Hamdu, 2020). Developing android mobile apps as a medium for learning mathematics based on a contextual approach can facilitate students' understanding of concepts (Basya, Rifa'i, \& Arfinanti, 2019).

The results of existing mobile learning developments are developed based on certain skills or knowledge to improve learning outcomes and mathematical performance. However, existing mobile learning has not been explicitly developed from basic mathematical knowledge in procedural and conceptual knowledge of elementary school students. Development needs to be done to overcome the problem of the low procedural and conceptual knowledge of students on fractional material (which can have an impact on students' low learning outcomes of fractional mathematics). Meanwhile, the needs of elementary school students during the Covid-19 pandemic are understanding fractions by constructing procedural and conceptual arrangements through mobile learning technology. Thus, the purpose of this study is to produce mobile learning based on procedural and conceptual knowledge on fractional (MoPCKF) for fifth-grade elementary school students.

\section{METHOD}

This research is included in the category of research and development (R\&D), which measures the validity, practicality, and effectiveness of a developed product. The development model used is the instructional model (ADDIE) in five phases: analysis, design, development, implementation, and evaluation. The analysis relates to the curriculum, needs, and characteristics of student learning to determine what products need to be developed and design product design activities as needed. Meanwhile, development is the manufacture and testing of products. Implementation is the activity of using the product. Evaluation is an activity to assess whether each activity and product step follows the specifications. The MoPCKF development phase can be seen in Figure 1 . The subjects in this study were one media expert, namely a lecturer in informatics engineering education, a material expert, a mathematics education lecturer, and eleven fifth-grade students at SD Negeri 4 Donomulyo. Data was collected using a questionnaire technique and also about pretest and posttest. The pretest and posttest questions consist of the same ten questions. The pretest questions are general questions, while the posttest questions are quizzes in the application. The 
question grid can be seen in Table 1. The questionnaire used in this study consisted of a validation questionnaire and a practicality questionnaire by adopting previous research on the development of mobile apps. The validity test was carried out by giving validation questionnaires to one mathematician education expert and one mobile learning technology media expert; the questionnaires for assessing material and media experts are in Table 2 and Table 3. Meanwhile, the product practicality questionnaire was given to research subjects. The practicality questionnaire outline can be seen in Table 4.

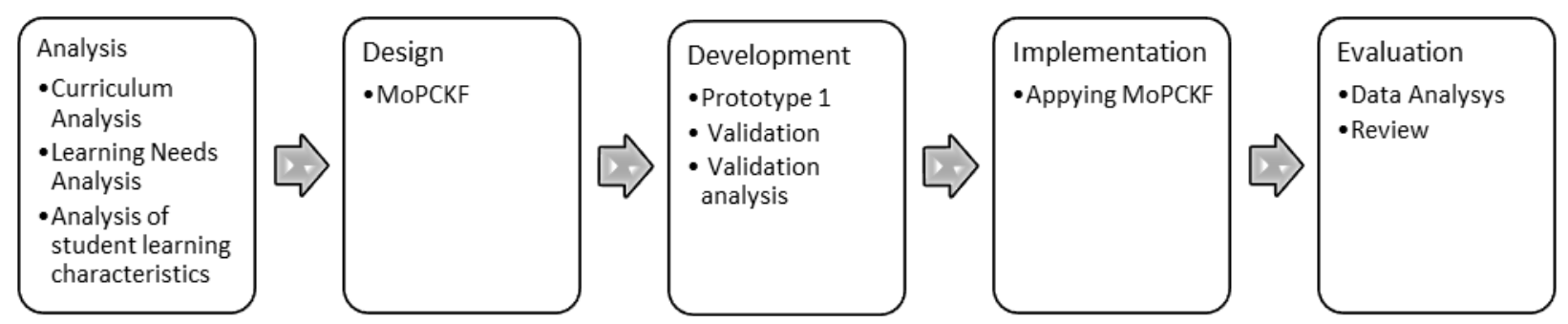

Figure 1. Mobile Learning Development Phase (Adapted From Parsazadeh et al., 2018)

Table 1. Outline of pretest dan posttest for the students

\begin{tabular}{|c|c|c|c|c|c|}
\hline Subject & Basic Competence & Indicator & Type & Grade & $\begin{array}{c}\text { Number of } \\
\text { Question }\end{array}$ \\
\hline \multirow[t]{2}{*}{ Mathematics } & $\begin{array}{l}3.1 \text { Explain and do the } \\
\text { addition and } \\
\text { subtraction of two } \\
\text { fractions with } \\
\text { different } \\
\text { denominators. }\end{array}$ & $\begin{array}{l}\text { Students can } \\
\text { calculate } \\
\text { addition, } \\
\text { fraction and } \\
\text { subtraction } \\
\text { correctly }\end{array}$ & Essay & 10 & $1,2,3,4,5$ \\
\hline & $\begin{array}{l}\text { 3.2 Explain and } \\
\text { perform the } \\
\text { multiplication and } \\
\text { division of decimal } \\
\text { fractions. }\end{array}$ & $\begin{array}{l}\text { Students are } \\
\text { able to do } \\
\text { multiplication } \\
\text { and division } \\
\text { correctly }\end{array}$ & Essay & 10 & $6,7,8,9,10$ \\
\hline
\end{tabular}

Table 2. Outline of material expert assessment instruments

\begin{tabular}{|c|c|c|c|}
\hline No & $\begin{array}{c}\text { Assessment } \\
\text { Aspect }\end{array}$ & Indicator & $\begin{array}{l}\text { Number of } \\
\text { Question }\end{array}$ \\
\hline 1. & $\begin{array}{l}\text { Material } \\
\text { Coverage }\end{array}$ & $\begin{array}{l}\text { Conformity of Indicators with Basic Competencies } \\
\text { Indicator suitability with learning objectives } \\
\text { The suitability of the material with the indicators and learning } \\
\text { objectives } \\
\text { Completeness of material following Basic Competence } \\
\text { Systematic presentation of the material following the cognitive } \\
\text { development of students }\end{array}$ & $1,2,3,4,5$ \\
\hline 2. & $\begin{array}{l}\text { Material } \\
\text { Accuracy }\end{array}$ & $\begin{array}{l}\text { The truth of the concept of Fraction Operation } \\
\text { The material presented has a clear reference source } \\
\text { Clarity of writing the formula and explanation of the formula } \\
\text { There are activities to observe Figures/events that help }\end{array}$ & $\begin{array}{l}6,7,8,9,10,1 \\
1,12,13\end{array}$ \\
\hline 3. & $\begin{array}{l}\text { Facilitating } \\
\text { Concept } \\
\text { Understandi } \\
\text { ng }\end{array}$ & $\begin{array}{l}\text { The activities were carried out to encourage students to ask } \\
\text { questions } \\
\text { or make a statement (ask) } \\
\text { There are steps to work on the problem as a model that } \\
\text { can be followed by students (reasoning) } \\
\text { There is an evaluation in the form of practice questions that } \\
\text { students can do } \\
\text { Some conclusions encourage students to synthesize } \\
\text { Some problems encourage students to understand the concept } \\
\text { There are examples and non-examples of a concept } \\
\text { There are practice problem-solving questions from a concept }\end{array}$ & $14,15,16$ \\
\hline
\end{tabular}


Table 3. Outline of media expert assessment instruments

\begin{tabular}{|c|c|c|c|}
\hline No & $\begin{array}{l}\text { Assessment } \\
\text { Aspect }\end{array}$ & Indicator & $\begin{array}{l}\text { Number of } \\
\text { Question }\end{array}$ \\
\hline 1. & $\begin{array}{l}\text { Component of } \\
\text { presentation }\end{array}$ & $\begin{array}{l}\text { Language Level Appropriatenes } \\
\text { Student development } \\
\text { Standard language used } \\
\text { Relationship between sentences } \\
\text { Relationships between paragraphs } \\
\text { The language used is following the rules of the language true } \\
\text { Indonesian } \\
\text { Consistency of use of terms }\end{array}$ & $1,2,3,4,5,6,7,8$ \\
\hline 2. & $\begin{array}{l}\text { Component of } \\
\text { appearance }\end{array}$ & $\begin{array}{l}\text { The suitability of the illustration with the substance of the } \\
\text { message } \\
\text { Ability to motivate students to respond to messages } \\
\text { Appropriateness of the layout and layout of the page } \\
\text { Linkage between views } \\
\text { Relation of view to material } \\
\text { Use of Figure } \\
\text { Clarity of letters, symbols, and symbols used } \\
\text { Text readability } \\
\text { Clarity of instructions for use } \\
\text { Clarity of appearance and color } \\
\text { Clarity of icons and buttons }\end{array}$ & $\begin{array}{l}9,10,11,12,13 \\
14,15,16,17 \\
18,19\end{array}$ \\
\hline 3. & $\begin{array}{l}\text { Software } \\
\text { engineering }\end{array}$ & $\begin{array}{l}\text { Learning media packaging gives an impression } \\
\text { Interesting }\end{array}$ & 20,21 \\
\hline 4. & Execution & $\begin{array}{l}\text { Appropriateness of the proportion of the image presented } \\
\text { Creative in pouring ideas or ideas } \\
\text { Ease and simplicity in operation } \\
\text { Initial display presentation that makes it easy to determine }\end{array}$ & $22,23,24,25$ \\
\hline
\end{tabular}

Table 4. Outline of the practicality questionnaire for students

\begin{tabular}{llll} 
No & $\begin{array}{l}\text { Assessme } \\
\text { nt Aspect }\end{array}$ & Indicator & $\begin{array}{c}\text { Number of } \\
\text { Question }\end{array}$ \\
\hline 1. & Function & $\begin{array}{l}\text { Ease of operation of mobile learning } \\
\text { Interest in using mobile learning }\end{array}$ & $1,2,3,4,5,6,7$, \\
& & $8,9,10,11,12$ \\
& & $\begin{array}{l}\text { Presentation of material based on procedural and conceptual } \\
\text { knowledge in mobile learning }\end{array}$ & \\
& & The influence of mobile learning on student motivation \\
& & The influence of mobile learning on concept understanding & \\
& & Satisfaction using mobile learning as a learning media & \\
\hline
\end{tabular}

The data from the product validation analysis is entered into the Gregory Table, a cross tabulation divided into four parts, namely A, B, C, D. The results of the data reflect the overall test produced. The categories for assessing the content of the validity of the questionnaire results are high $(>0.8)$, moderate (0.4-0.8), and low $(<0.4)$ (Retnawati, 2016). The results of the expert's assessment are in the interval $>0.8$, so the assessment instrument is very valid. This shows that the questionnaire is feasible to assess the validity and practicality of mobile learning. Mobile learning is said to be valid if the data results are in the interval 2.50 Rv 4.00. Furthermore, the test was conducted on 11 fifth-grade students of SD Negeri 4 Donomulyo. Mobile learning is said to be practical if the results of data analysis are in the interval $2.50 \mathrm{Rk}$ 4.00 (Mudiartana et al., 2021).

\section{RESULT AND DISCUSSION}

\section{Result}

Knowledge-based and conceptual mobile learning in fractional material was developed with the ADDIE development model (analysis, design, development, implementation, evaluation). The stages of mobile learning development start from the analysis stage, carried out with curriculum analysis, learning 
needs analysis, and student learning characteristics. At this stage, the analysis is carried out on the Core Competencies (CC) and Expected Competencies (BC) of the class V fractional operation material. Students produce information that the media used on average are photos of learning materials from books, voice messages, and YouTube videos sent via the WhatsApp application. The teacher admitted that finding an appropriate learning video was difficult and could facilitate understanding the concept. The existing learning tended only to send photos of material books and short voice messages. Students also informed that they had difficulty with the material, which was usually given directly by way of completion or procedural without explaining the concept of fractions. In the Student Characteristics Analysis phase, students aged 13-15 have not understood symbolic thinking skills. Thus, they still need media for learning resources. The teacher said that students did not understand the fraction operation material in this online learning because the available media only supports one knowledge, for example, only procedural or conceptual.

Table 6. The results of the $\mathrm{CC}$ and $\mathrm{BC}$ analysis of the fraction operation material in the fifth grade

\begin{tabular}{|c|c|c|c|c|}
\hline $\begin{array}{c}\text { Core } \\
\text { Competencies }\end{array}$ & $\begin{array}{c}\text { Basic } \\
\text { Competencies }\end{array}$ & $\begin{array}{l}\text { Indicators of } \\
\text { Competency } \\
\text { Achievement }\end{array}$ & Materials & $\begin{array}{l}\text { Learning } \\
\text { Activities }\end{array}$ \\
\hline CC-3 & $\begin{array}{l}\text { 3.1 Explain and } \\
\text { perform the } \\
\text { addition and } \\
\text { subtraction of two } \\
\text { fractions with } \\
\text { different decimal } \\
\text { denominators. }\end{array}$ & $\begin{array}{l}\text { 3.1.1 Explain the addition } \\
\text { of two fractions with } \\
\text { different denominators } \\
\text { 3.1.2 Explain the } \\
\text { subtraction of two } \\
\text { different fractions } \\
\text { 3.1.3 Adding two fractions } \\
\text { with different } \\
\text { denominators }\end{array}$ & $\begin{array}{l}\text { Fraction } \\
\text { Operation }\end{array}$ & $\begin{array}{l}\text { Learning } \\
\text { activities are } \\
\text { conducted online } \\
\text { by giving } \\
\text { assignments to } \\
\text { students and } \\
\text { also pictures of } \\
\text { learning } \\
\text { materials }\end{array}$ \\
\hline CC-3 & $\begin{array}{l}\text { 3.2 Explain and do } \\
\text { multiplication and } \\
\text { division of fractions }\end{array}$ & $\begin{array}{l}\text { 3.2.1 Explain } \\
\text { multiplication of decimal } \\
\text { fractions } \\
\text { 3.2.2 Explain the division } \\
\text { of decimal fractions } \\
\text { 3.2.3 Multiply decimal } \\
\text { fractions } \\
\text { 3.2.4 Doing decimal } \\
\text { fraction division }\end{array}$ & $\begin{array}{l}\text { Decimal } \\
\text { Fraction } \\
\text { Operation }\end{array}$ & $\begin{array}{l}\text { Learning } \\
\text { activities are } \\
\text { conducted online } \\
\text { by giving } \\
\text { assignments to } \\
\text { students and } \\
\text { also pictures of } \\
\text { learning } \\
\text { materials }\end{array}$ \\
\hline
\end{tabular}

Design Phase. The design phase involves mapping the content in mobile learning, as shown in Figure 2. This framework includes core competencies that contain explanations of core competencies that students must achieve, basic competencies that contain explanations of basic competencies regarding fractional operations that students in learning must master, and study tips containing tips for student learning when studying remotely using mobile devices learning. The other components contain material in the form of procedural nature and a video menu containing learning videos containing conceptual knowledge related to fractional operations. In addition, there is a quiz component that contains practice questions that students can use to test their understanding of the fraction operation material. This design phase also includes instrument design and validation, which will later be used for the validation process after the product is made.

Development Phase. The Mobile Learning application was developed using Android Studio software, Android Virtual Devices Manager, Java Development kit 8u45, and Android SDK. Minimum hardware requirements for development are IntelCore i5 processor, 8Gb RAM, and VGA NVidia 710. Android Marshmellow or higher with minimum hardware specifications of 3Gb RAM also becomes a minimum requirement. The researcher carried out several processes at the product design stage, namely layout design, storyboard design, content content, and usage instructions, to design the cover using an online editing site, namely Canva.com and Corel Draw. The display of some content in mobile learning can be seen in Figures 3 and Figure 4. The validity of mobile learning can be seen from material experts and media experts (one lecturer in mathematics education and one lecturer in information technology education. The assessment results from material experts scored 3.76 were in the interval $2.50 \mathrm{Rv} 4.00$, which indicates that mobile learning is valid. The assessment results from media experts are 3.43 , which is at the interval of $2.50 \mathrm{Rv} 4.00$, which indicates that mobile learning is valid. The next stage after mobile learning is said to be valid and practical, namely the implementation stage. This implementation stage is a 
stage to determine the practicality of the resulting product, namely procedural and conceptual-based mobile learning. Students are given a questionnaire containing response items to assess the practicality of mobile learning. Based on field trials on 11 students of SD Negeri 4 Donomulyo, it can be seen that mobile learning has an average practicality score $\mathrm{n} 3.82$ is in the interval $2.50 \mathrm{Rk} 4.00$, so it is said to be practical. There were no obstacles in implementation; students managed to install and use the existing mobile learning on their cellphones. Criticisms and suggestions from students' responses after using mobile learning were "fun," "it's fun to learn through videos and existing quizzes," and "cool can be studied at home anytime."

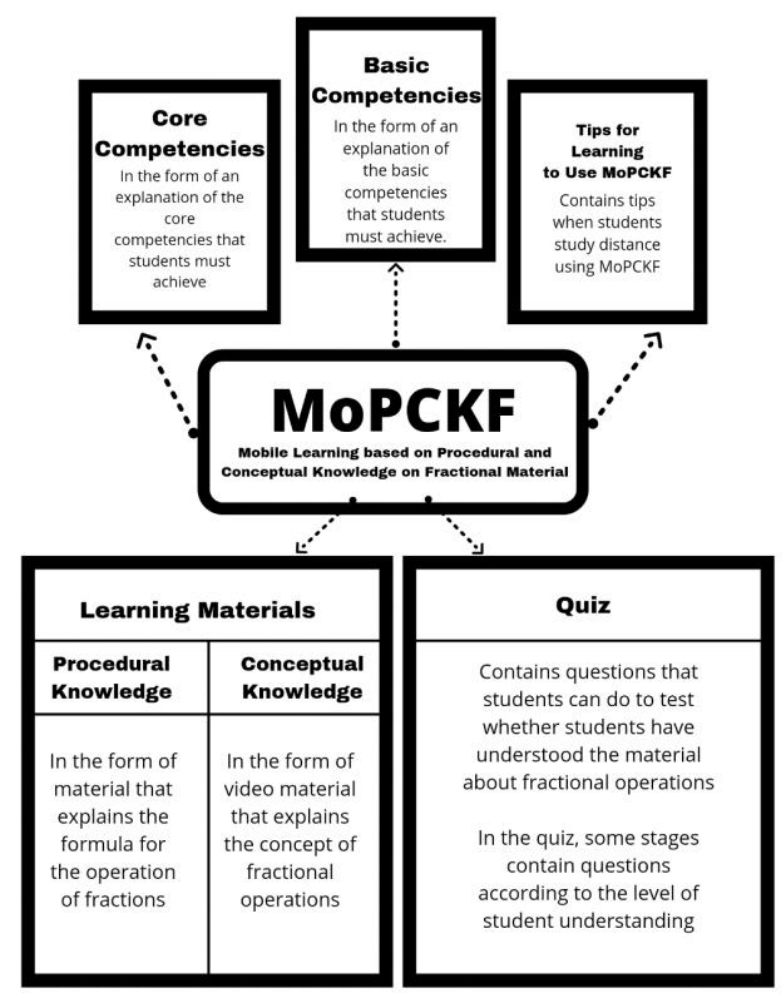

Figure 2. The MoPCKF content map

Evaluation Phase. This evaluation stage includes data analysis of student learning outcomes before the use of mobile learning and after the use of mobile learning. The analysis was carried out using the SPSS for Windows analysis program. The statistic of the normality test used was the Shapiro Wilk test, which resulted in a pretest significance of 0.017 . Meanwhile, the posttest significance shows a value of 0.009 , or less than 0.05 , which means that the data is not normally distributed. The test statistic used next is the Wilxocon test because the data is not normally distributed. Wilcoxon's test shows a significance value of 0.010 , which is $<0.05$. This means that there is a difference in the average results before and after using mobile learning, which influences student learning outcomes. In addition to data analysis, the evaluation phase also includes a review to determine the feasibility of the resulting MoPCKF product in elementary school. The review stage allows the researcher to evaluate the previous stage. The needs analysis stage concludes that when mobile learning does not exist, the teacher uses the WhatsApp messaging application to convey the existing material. Students admit that it is difficult to understand the material if they are only sent photos of it and go directly to the methods or formulas for solving them. The design stages include content mapping and prototyping. The validation stage includes media experts, material experts. Media experts are lecturers of information engineering education, and material experts are lecturers of mathematics education. The results of the expert assessment obtained an average of 3.59 with a valid category. The results of student assessment obtained an average of 3.82 in the practical category. The results of data analysis show that there is an influence on the use of mobile learning on student learning outcomes. The conclusion is that mobile learning is valid, practical, and effective in accompanying student learning activities. 


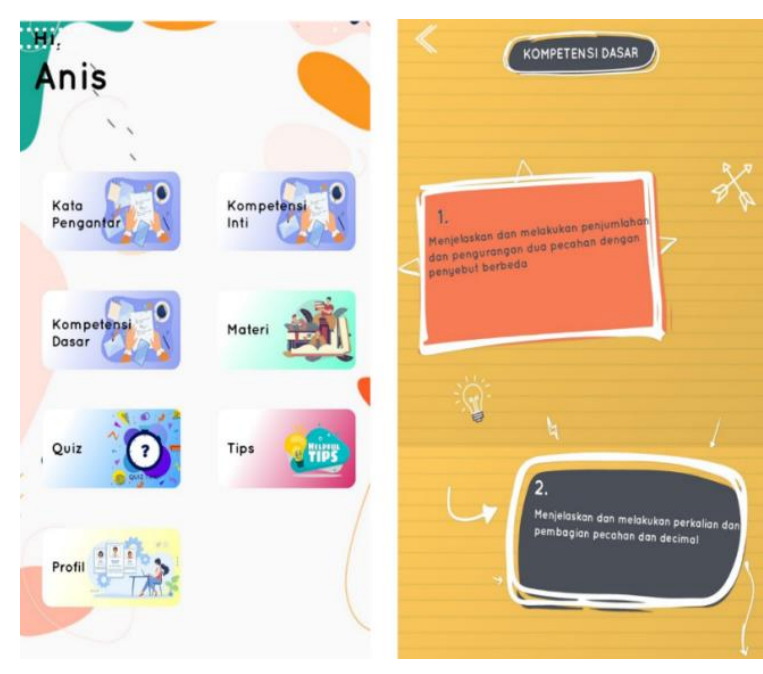

Figure 3. Main menu display and also basic competencies

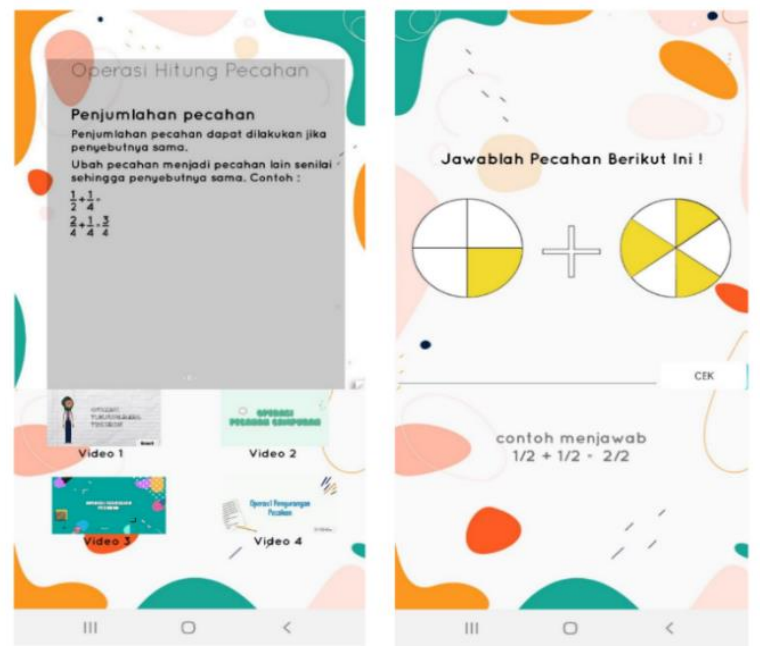

Figure 4. Display of procedural knowledge and quiz

\section{Discussion}

The researcher succeeded in presenting the mobile learning media that has been validated by experts with excellent value and is feasible to use. The results are inseparable from the stages of development carried out. The analysis phase describes the need for mobile learning. Mobile learning can enable educators to produce online learning solutions for students anywhere and anytime (Jou et al., 2016; Sletten \& Montebello, 2021). The results of the analysis show that the required mobile learning is based on procedural and conceptual knowledge. During the COVID-19 pandemic, learning media in mobile learning is needed because it can accompany learning and improve elementary school students' mathematics learning outcomes (Firdaus \& Hamdu, 2020; Peiyan, 2021). Mobile learning that contains procedural and conceptual knowledge is needed to construct understanding (Amir et al., 2020) and procedural mathematical steps in solving fractions (Rittle-johnson \& Schneider, 2019; Sari et al., 2021). In addition, mobile learning developed from a specific skill framework can be used to evaluate the development of the skill itself (Parsazadeh et al., 2018). Therefore, mobile learning includes procedural and conceptual knowledge that can help students understand the material and the steps of mathematical completion to improve students' mathematics learning outcomes (Hamdani, 2016).

Existing mobile learning is mapped in the design stage by covering content that supports procedural and conceptual knowledge. Procedural knowledge is packaged in a video and a module to understand how the steps for solving fraction operations are not only in material scripts that must be studied. Conceptual knowledge is also packaged with a video to gain knowledge more enthusiastically because students can see directly through the illustrations displayed. Learning using videos makes children more enthusiastic about learning (Anugrahana, 2020). Using videos, packaging procedural and conceptual knowledge can also provide accurate information to students (Mayarnimar \& Taufina, 2017). A quiz menu also accompanies mobile learning to measure student understanding in the form of practice questions regarding the material studied to evaluate and measure understanding of student learning outcomes (Kuncahyono, Suwandayani, \& Muzakki, 2020). Validation instruments are also created in this phase to be used as an assessment of the product.

The development of mobile learning is said to be valid and practical to use to assist student learning. Mobile learning is said to be valid if it meets the material requirements, the language is easy to understand, and is under the characteristics of students (Alhafidz \& Haryono, 2018; Liu, Kong, Jiang, \& Li, 2021; Rahardjo, Degeng, \& Soepriyanto, 2019). The validity of the product development results impacts a better understanding of students' material (Nurhalimah et al., 2017). In addition, the results of the development of valid procedural and conceptual knowledge-based mobile learning can be used to evaluate the achievement and development of procedural and conceptual skills (Parsazadeh et al., 2018). Meanwhile, the practicality of mobile learning shows that the mobile learning developed is easy to use, has no obstacles in its use, is attractive to students, and helps students understand concepts. The practicality of mobile learning products shows students' positive responses to mobile learning to support and assist students' learning needs (Chen \& Tsai, 2021; Humaidi et al., 2021).

This study also shows that students experience an increase in learning outcomes, which means that mobile learning is effective. The effectiveness of the media can be measured through differences in student learning outcomes (Alhafidz \& Haryono, 2018). The evaluation also shows that mobile learning is effective 
in improving student learning outcomes. The increase in students' mathematics learning outcomes is due to meaningful learning process activities through learning videos and fractional material construction oriented to procedural and conceptual knowledge of fractions. Mathematical learning activities that are structured explain the completion procedures systematically lead to clear and sequential mathematical completion steps (Legesse et al., 2020; Rittle-johnson \& Schneider, 2019). Mathematics learning activities based on conceptual knowledge impact positive mathematics learning outcomes (Afra et al., 2020; Devi \& Amir, 2021). The development of MoPCKF can improve the learning outcomes of elementary school students' fractions. The development of mobile technology in iPad Fractions Game Motion Math significantly increases fractions knowledge (procedural and conceptual (Kay \& Kwak, 2018). The development of mobile learning impacts students' mathematics learning processes and outcomes (Bernacki, Greene, \& Crompton, 2020). The development of mobile learning impacts students' mathematics learning processes and outcomes (Zhang, Shang, Pelton, \& Pelton, 2020). The implementation of mobile applications in authentic contexts for learning mathematics for elementary school students has an impact on improving learning outcomes and learning behaviors on fractions material. It leads to a conceptual understanding of fractions (Hwang, Utami, Purba, \& Chen, 2020). This study resulted in a product in MoPCKF in the fifth-grade elementary school fraction material, which was tested for validity, practicality, and effectiveness. Although, this mobile learning has not been tested with a large number of primary school student participants. The results of this study imply that mobile learning was developed as an alternative solution for teachers and fifth-grade elementary school students in online learning activities during the Covid-19 pandemic. This is because its use is not limited by time and place. The development of mobile learning based on conceptual and procedural knowledge increases student learning outcomes, and learning becomes meaningful. The results of this study can be used as a reference for other researchers who want to develop similar products.

\section{CONCLUSION}

The development of MoPCKF is feasible, practical, and effective to use with outstanding categories. Judging from the material aspect, the media aspect and can improve student learning outcomes. So, it can be recommended that MoPCKF be used as an alternative for learning mathematics.

\section{REFERENCES}

Abidin, Z., Hudaya, A., \& Anjani, D. (2020). Efektivitas Pembelajaran Jarak Jauh pada Masa Pandemi Covid19. Journal of Education, 1(October), 131-146. Retrieved from. https://dx.doi.org/10.30998/rdje.v1i1.7659.

Abqari, F. T., Irawan, B. E., \& Sa'dijah, C. (2018). Media Permainan Kartu Domino untuk Meningkatkan Keterampilan Berhitung Konversi Pecahan Desimal Siswa Kelas IV. Jurnal Pendidikan: Teori, Penelitian, Dan Pengembangan, 3(9), 1190-1199. Retrieved from http://dx.doi.org/10.17977/jptpp.v3i9.11550.

Afra, Y., Rahmawati, P., \& Widya, F. A. (2020). Pengaruh Media Papan Puzzle Terhadap Pemahaman Konseptual Matematika Siswa di Sekolah Dasar. Jurnal Pendidikan Dasar, 8(2), 74-86. Retrieved from https://doi.org/10.46368/jpd.v8i2.205.

Alhafidz, M. R. L., \& Haryono, A. (2018). Pengembangan Mobile Learning Berbasis Android sebagai Media Pembelajaran Ekonomi. Jurnal Pendidikan Ekonomi, 11(2), 118-124. Retrieved from https://dx.doi.org/10.17977/UM014v11i22018p010.

Amir, M.F., Ariyanti, N., Anwar, N., Valentino, E., \& Afifah, D. S. N. (2020). Augmented reality mobile learning system: Study to improve PSTs' understanding of mathematical development. International Journal of Interactive Mobile Technologies, 14(9). https://doi.org/10.3991/ijim.v14i09.12909.

Amir, Mohammad Faizal, Hasanah, F. N., \& Musthofa, H. (2018). Interactive Multimedia Based Mathematics Problem Solving to Develop Student s ' Reasoning. International Journal of Engineering \& Technology, 7, 272-276. Retrieved from https://doi.org/10.14419/ijet.v7i2.12.14691.

Anugrahana, A. (2020). Hambatan, Solusi dan Harapan: Pembelajaran Daring Selama Masa Pandemi Covid19 Oleh Guru Sekolah Dasar. Scholaria: Jurnal Pendidikan Dan Kebudayaan, 10(3), 282-289. https://doi.org/10.24246/j.js.2020.v10.i3.p282-289.

Astalini, Darmaji, Kurniawan, W., Khairul, A., \& Kurniawan, D. A. (2019). Effectiveness of Using E-Module and E-Assesment. Jurnal Pedagogik, 21-39. https://doi.org/https://doi.org/10.3991/ijim.v13i09.11016.

Bano, M., Zowghi, D., Kearney, M., Schuck, S., \& Aubusson, P. (2018). Computers \& Education Mobile learning for science and mathematics school education: A systematic review of empirical evidence. 
Computers \& Education, 121(February), 30-58. https://doi.org/10.1016/j.compedu.2018.02.006.

Basya, Y. F., Rifa'i, A. F., \& Arfinanti, N. (2019). Pengembangan Mobile Apps Android Sebagai Media Pembelajaran Matematika Berbasis Pendekatan Konstektual untuk memfasilitasi Pemahaman Konsep. Jurnal Pengembangn Pembelajaran Matematika (JPPM), I(1), 1-9. Retrieved from https://doi.org/10.14421/jppm.2019.011-01.

Bernacki, M. L., Greene, J. A., \& Crompton, H. (2020). Mobile technology, learning, and achievement: Advances in understanding and measuring the role of mobile technology in education. $\begin{array}{llll}\text { Contemporary } & \text { Educational } & \text { Psychology, } & 601827 .\end{array}$ https://doi.org/10.1016/j.cedpsych.2019.101827.

Chen, C.-C., \& Tsai, H.-C. (2021). In-service teachers' conceptions of mobile technology-integrated instruction: Tendency towards student-centered learning. Computers and Education, 170(May), 104224. https://doi.org/10.1016/j.compedu.2021.104224.

Damian, C., Naibaho, U., Agung, I. G., \& Wulandari, A. (2021). Kontribusi Intensitas Pemakaian Gadget dan Peran Orang Tua Terhadap Hasil Belajar Matematika Siswa Kelas V SD. Jurnal Pedagogi Dan Pembelajaran, 4(1), 59-68. Retrieved from http://dx.doi.org/10.23887/jp2.v4i2.31834.

Demir, K., \& Akpinar, E. (2018). The effect of mobile learning applications on students ' academic achievement and attitudes toward mobile learning. Malaysian Online Journal of Educational Technology, 6(2), 48-59. Retrieved from https://dx.doi.org/10.17220/mojet.2018.04.004.

Devi, M. S. A., \& Amir, M. F. (2021). Analisis Kesalahan Konseptual dan Prosedural Siswa Sekolah Dasar dalam Menggeneralisasi Pola Bilangan. AKSIOMA: Jurnal Program Studi Pendidikan Matematika, 10(3), 1336-1350. https://doi.org/10.24127/ajpm.v10i3.3713.

Firdaus, S., \& Hamdu, G. (2020). Pengembangan Mobile Learning Video Pembelajaran Berbasis STEM (Science, Technology, Engineering and Mathematic) di Sekolah Dasar. Jurnal Inovasi Teknologi Pembelajaran, 7(2), 66-75. https://doi.org/10.17977/um031v7i22020p066.

Galvin, R., Dütschke, E., \& Weiß, J. (2021). A conceptual framework for understanding rebound effects with renewable electricity : A new challenge for decarbonizing the electricity sector. Renewable Energy, 176, 423-432. https: //doi.org/10.1016/j.renene.2021.05.074.

Hamdani. (2016). Meningkatkan Pengetahuan Konseptual Dan Pengetahuan Prosedural Mahasiswa Melalui Pendekatan Diskursus Matematik. Jurnal Pendidikan Matematika Dan IPA, 6(1), 13-25. https://doi.org/10.26418/jpmipa.v6i1.16221.

Harahap, A. C. P., Harahap, D. P., \& Harahap, S. R. (2020). Analisis Tingkat Stres Akademik Pada Mahasiswa Selama Pembelajaran Jarak Jauh Dimasa Covid-19. Biblio Couns: Jurnal Kajian Konseling Dan Pendidikan, 3(1), 10-14. https://doi.org/10.30596/bibliocouns.v3i1.4804.

Herzamzam, D. A. (2021). Pembelajaran Jarak Jauh menggunakan Aplikasi Zoom pada Matakuliah Pendidikan Matematika SD 1. Edukatif: Jurnal Ilmu Pendidikan, 3(5), 2664-2675. Retrieved from https://doi.org/10.31004/edukatif.v3i5.891.

Humaidi, H., Qohar, A., \& Rahardjo, S. (2021). Respon Siswa terhadap Penggunaan Video Youtube sebagai Media Pembelajaran Daring Matematika. JIPM (Jurnal Ilmiah Pendidikan Matematika), 10(2), 153. https://doi.org/10.25273/jipm.v10i2.9108.

Hwang, G. J., Wang, S. Y., \& Lai, C. L. (2020). Effects of a social regulation-based online learning framework on students' learning achievements and behaviors in mathematics. Computers and Education, 160, 104031. https://doi.org/10.1016/j.compedu.2020.104031.

Hwang, W. Y., Utami, I. Q., Purba, S. W. D., \& Chen, H. S. L. (2020). Effect of Ubiquitous Fraction App on Mathematics Learning Achievements and Learning Behaviors of Taiwanese Students in Authentic Contexts. IEEE Transactions on Learning Technologies, 13(3), 530-539. https://doi.org/10.1109/TLT.2019.2930045.

Jou, M., Tennyson, R. D., Wang, J., \& Huang, S. Y. (2016). A study on the usability of E-books and APP in engineering courses: A case study on mechanical drawing. Computers and Education, 92-93, 181193. https://doi.org/10.1016/j.compedu.2015.10.004.

Kay, R., \& Kwak, J. Y. (2018). Comparing types of mathematics apps used in primary school classrooms: an exploratory analysis. Journal of Computers in Education, 5(3), 349-371. https://doi.org/10.1007/s40692-018-0109-X.

Khachfe, H. H., Chahrour, M., Sammouri, J., Salhab, H. A., Makki, B. E., \& Fares, M. Y. (2020). An Epidemiological Study on COVID-19: A Rapidly Spreading Disease. Cureus, 12(3). https://doi.org/10.7759/cureus.7313.

Kuncahyono, Suwandayani, B. I., \& Muzakki, A. (2020). Aplikasi E-Test “That Quiz" sebagai Digitalisasi Keterampilan Pembelajaran Abad 21 di Sekolah Indonesia Bangkok. Lectura: Jurnal Pendidikan, 29(9), 1890-1896. Retrieved from https://doi.org/10.7759/cureus.7541.

Lage-Cala, S., Folgueras-Díaza, M. B., Alonso-Hidalgoa, M., García-Menéndezb, D., \& Fernández-Garcíab, F. J. 
(2020). Investigation of the effectiveness of online learning tools for energy performance certificates preparation. Energy Reports, 6, 609-614. https://doi.org/10.1016/j.egyr.2019.09.034.

Legesse, M., Luneta, K., \& Ejigu, T. (2020). Analyzing the effects of mathematical discourse-based instruction on eleventh-grade students' procedural and conceptual understanding of probability and statistics. $\begin{array}{llll}\text { Studies in Educational } & 100918 .\end{array}$ https://doi.org/10.1016/j.stueduc.2020.100918.

Liu, X., Kong, J., Jiang, M., \& Li, S. (2021). Interactive information module for person re-identification. Journal of Visual Communication and Image Representation, 75(November 2019), 103033. https://doi.org/10.1016/j.jvcir.2021.103033.

Mayarnimar, \& Taufina. (2017). Validity Analisis of the VARK ( Visual , Auditory , Read- Write , and Kinesthethic ) Model - Based Basic Reading and Writing Instructional Msterials For The 1st Grade. Advances in Social Science and Humanities Research, 118, 870-874. Retrieved from https://doi.org/10.2991/icset-17.2017.141.

Mishra, D. L., Gupta, D. T., \& Shree, D. A. (2020). Online Teaching-Learning in Higher Education during Lockdown Period of COVID-19 Pandemic. International Journal of Educational Research Open, 1, 100012. https://doi.org/10.1016/j.ijedro.2020.100012.

Mudiartana, I. M., Margunayasa, I. G., \& Divayana, D. G. H. (2021). How is The Development of Valid and Practical Android- Based Local Wisdom Teaching Materials ? Jurnal Ilmiah Sekolah Dasar, 5(3), 403-414. Retrieved from http://dx.doi.org/10.23887/jisd.v5i3.38176.

Mukrimatin, N. A., Murtono, \& Wanabuliandri, S. (2018). Pemahaman Konsep Matematika Siswa Kelas V SD Negeri RAU Kedung Jepara Pada Materi Perkalian Pecahan. Jurnal Ilmiah Pendidikan Matematika, 1(1), 67-71. Retrieved from https://doi.org/10.24176/anargya.v1i1.2277.

Nugroho, A. A., \& Purwati, H. (2018). Pengembangan Media Pembelajaran Matematika Berbasis Mobile Learning Dengan Pendekatan Scientific. Jurnal Euclid, 2(1), 174-182. Retrieved from http://dx.doi.org/10.33603/e.v2i1.355.

Nurhalimah, S. R., Suhartono, S., \& Cahyana, U. (2017). Pengembangan Media Pembelajaran Mobile Learning Berbasis Android pada Materi Sifat Koligatif Larutan. JRPK: Jurnal Riset Pendidikan Kimia, 7(2), 160-167. https://doi.org/10.21009/jrpk.072.10.

Nurhayati, Aswar, \& Arifin, I. (2018). Komik Sebagai Media Pembelajaran Matematika Bagi Siswa Sekolah Dasar. Jurnal Imajinasi Seni Dan Pendidikan, 2, 26-34. Retrieved from https://doi.org/10.26858/i.v2i2.9550.

Oppermann, E., \& Lazarides, R. (2021). Elementary school teachers' self-efficacy, student-perceived support and students' mathematics interest. Teaching and Teacher Education, 103, 103351. https://doi.org/10.1016/J.TATE.2021.103351.

Oyedotun, T. D. (2020). Sudden change of pedagogy in education driven by COVID-19: Perspectives and evaluation from a developing country. Research in Globalization, 2(June), 100029. https://doi.org/10.1016/j.resglo.2020.100029.

Paridi. (2019). Peningkatan hasil belajar matematika materi operasi hitung pecahan melalui penerapan model pembelajaran kooperatif tipe jigsaw. Jurnal Pendidikan Dan Ilmu Sosial, 1(1), 96-108. Retrieved from https://doi.org/10.36088/pensa.v1i1.337.

Parsazadeh, N., Ali, R., \& Rezaei, M. (2018). A framework for cooperative and interactive mobile learning to improve online information evaluation skills. Computers and Education, 120(May 2017), 75-89. https://doi.org/10.1016/j.compedu.2018.01.010.

Patricia, A. (2020). College Students' Use and Acceptance of Emergency Online Learning Due to COVID-19. International Journal of Educational Research Open, 100011. https://doi.org/10.1016/j.ijedro.2020.100011.

Peiyan, C. (2021). Thinking skills development in mobile learning : The case of elementary school students studying environmental studies. Thinking Skills and Creativity, 42(August), 100922. https://doi.org/10.1016/j.tsc.2021.100922.

Rafiq, B., \& Mailili, H. W. (2019). Profil Pengetahuan Konseptual Matematis Siswa ditinjau dari Gaya Kognitif. ANARGAYA: Jurnal Ilmiah Pendidikan Matematika, 2(1), 7-12. Retrieved from https://doi.org/10.24176/anargya.v2i1.3080.

Rahardjo, T., Degeng, I. N. S., \& Soepriyanto, Y. (2019). Pengembangan Multimedia Interaktif Mobile Learning Berbasis Anrdroid Aksara Jawa Kelas X Smk Negeri 5 Malang. Jurnal Kajian Teknologi Pendidikan, 2(3), 195-202. https://doi.org/10.17977/um038v2i32019p195.

Retnawati, H. (2016). Analisis Kuantitatif Instrument Penelitian. In Academia.Edu. Retrieved from. www.nuhamedika.gu.ma.

Rittle-johnson, B., \& Schneider, M. (2019). Developing Conceptual and Procedural Knowledge of Mathematics. In Oxford University Press (pp. 1-22). Retrieved from 
https://doi.org/10.1093/oxfordhb/9780199642342.013.014.

Sahu, P. (2020). Closure of Universities Due to Coronavirus Disease 2019 (COVID-19): Impact on Education and Mental Health of Students and Academic Staff. Cureus, 2019(4), 4-9. https://doi.org/10.7759/cureus.7541.

Saputra, W. B., Utami, N. W., \& Kusuma, I. A. (2021). Developing Culture-Based Mathematics Learning Media with Adobe Flash for JHS Students. Journal of Physics: Conference Series, 1823(1), 1-10. https://doi.org/10.1088/1742-6596/1823/1/012114.

Sari, L. P., Degeng, I. N. S., \& Praherdhiono, H. (2021). Pengembangan Multimedia Tutorial Untuk Memfasilitasi Kognitif Prosedural. JKTP: Jurnal Kajian Teknologi Pendidikan, 4(2), 158-167. https: //doi.org/10.17977/um038v4i22021p158.

Sletten, M., \& Montebello, M. (2021). Secure Mobile Learning. Procedia Computer Science, 191, 431-436. https://doi.org/10.1016/j.procs.2021.07.054.

Suarjana, I. M., Parmiti, D. P., \& Safitri, P. E. A. (2018). Analisis Kesulitan Siswa Dalam Menyelesaikan Operasi Hitung Pecahan Siswa Sekolah Dasar. International Journal of Elementary Education, 2(2), 144-155. Retrieved from http://dx.doi.org/10.23887/ijee.v2i2.14417.

Suhady, W., Roza, Y., \& Maimunah, M. (2019). Identifikasi Kesalahan Konseptual Dan Prose dural Siswa Dalam Menyelesaikan Soal Pada Materi Dimensi Tiga. Jurnal Cendekia: Jurnal Pendidikan Matematika, 3(2), 494-504. https://doi.org/10.31004/cendekia.v3i2.143.

Sulastri, A. (2016). Penerapan Pendekatan Konstekstual dalam Pembelajaran Matematika untuk Meningkatkan Pemahaman Konsep Matematis Siswa Sekolah Dasar. Jurnal Pendidikan Sekolah Dasar, 1(1), 156-170. Retrieved from https://doi.org/10.17509/jpgsd.v1i1.9068.

Suwarto. (2018). Konsep Operasi Bilangan Pecahan melalui Garis Bilangan. Mosharafa: Jurnal Pendidikan Matematika, 7(3), 327-336. https://doi.org/10.31980/mosharafa.v7i3.73.

Talib, A. (2017). Analisis Pemahaman Konseptual dan Prosedural Siswa dalam Menyelesaikan Soal Matematika Berdasarkan Gaya Belajar. Issues in Mathematics Education (IMED), 1(2), 101-106. Retrieved from. https://doi.org/10.35580/imed9469.

Wawan, Talib, A., \& Djam'an, N. (2019). Analisis Pemahaman Konseptual dan Prosedural Siswa dalam Menyelesaikan Soal Matematika Berdasarkan Gaya Belajar. Issues in Mathematics Education (IMED), 1(2), 101-106. Retrieved from. https: //doi.org/10.35580/imed9469.

Weisberger, M., Grinshtain, Y., \& Blau, I. (2021). How do technological changes in formal education shape the social roles of teachers who are mothers? Teaching and Teacher Education, 103, 103344. https://doi.org/10.1016/j.tate.2021.103344.

Widiastika, M. A., Hendracipta, N., \& Syachruroji, A. (2021). Pengembangan Media Pembelajaran Mobile Learning Berbasis Android pada Konsep Sistem Peredaran Darah di Sekolah Dasar. JURNAL BASICEDU, 5(1), 47-63. Retrieved from. https://doi.org/10.31004/basicedu.v5i1.602.

Zhang, L., Shang, J., Pelton, T., \& Pelton, L. F. (2020). Supporting primary students' learning of fraction conceptual knowledge through digital games. Journal of Computer Assisted Learning, 36(4), 540548. https://doi.org/10.1111/jcal.12422. 